\title{
Constituents Process of Marriage Advices by Hatobangon (Traditional Leader) in Angkola Language
}

\author{
Husniah Ramadhani Pulungan ${ }^{1}$, Riyadi Santosa ${ }^{2}$, Djatmika $^{3}$, and Tri Wiratno ${ }^{4}$ \\ 1,2,3,4 Universitas Sebelas Maret, Surakarta, Indonesia \\ ${ }^{1}$ husniahpulungan@gmail.com
}

\begin{abstract}
Marriage advice is one of the texts that is still limited in Functional Systemic Linguistic (LSF) analysis. This is because several studies related to marriage have been carried out starting from tradition, speech discourse, traditional procession, communication, cultural and religious relations, courtesy, the law, educational values in marriage. Based on this, the gap in this paper is only in the analysis of a marriage advice text from one of the traditional leaders (in this case hatobangon). In order to fill the gap in this paper, the analysis used is LSF especially from the experiential process which is focused only on the constituents of the process. The data source is the marriage advice text from hatobangon which consists of eighty-three clauses. The investigation that has been carried out has proven that hatobangon's tendency to convey Angkola-language marriage advice uses a process: mental behavioral as much and pricked by process: relational. This finding shows that the text of the advice tends to use the wisdom side and the parable side as a form of valuable guidelines for the bride and groom at Angkola.
\end{abstract}

Keywords: Culture; Traditional Leader; Constituent Process; Marriage; Angkola Laguage

\section{INTRODUCTION}

Angkola is a cultural area in South Tapanuli Regency, North Sumatra Province, Indonesia. The Angkola community still adheres to their traditions from generation to generation. One of the cultural customs in the community is a traditional wedding event. Marriage in the cultural area of Angkola is known as marripe. There are nine types of marriages that are known in the Angkola community culture, starting from na patugincatkon, tangko binoto, boru manaek, boru elehan, boru hiapan, boru mangalap tungkot, maninian, elopement, and manjujur [1]. In addition to being supported by a form of society that is based on family relations between people, this cultural custom is also inseparable from those who 
regulate the occurrence of traditional events. The parties involved in regulating tradition consist of five people, namely: the king, the rich, the descendants of the king (harajaon), hatobangon, hulu balang [2]. These people have their respective functions and roles in every traditional ceremony, especially in a wedding.

Furthermore, seeing this cultural custom is interesting to study, the researchers tried to observe several studies related to marriage that had been carried out starting from tradition, speech discourse, traditional procession, communication, cultural and religious relations, adab, to the law, educational values in marriage [3]-[27].

However, based on the research view above, it can be seen that the analysis related to marriage advice is still limited, especially in the analysis of the experimental process. Plus the marriage advice analyzed came from traditional leaders who made this matter even more interesting to study. Considering that in the Angkola region, there are some interesting traditional leaders traced to how they see the world in terms of the traditional role they hold, and researchers are motivated to know how the experiential process of traditional leaders in providing Angkola language marriage advice.

Before exploring further how traditional leaders see the world from their perspective, it will first be explained who is a traditional figure named hatobangon. Hatobangon according to [1] explained that hatobangon was a messenger (representative) of a particular group of people that have same family name (semarga) or different family name (marga). In addition, this hatobangon can suggest the aspirations of his group to share common interests in the community, both in demanding customary rights and in carrying out customary obligations. Then, the requirement to become hatobangon ni huta consisted of: participating as the founder of a huta, kahanggi from the founder of huta, the son of boru from the founder of the huta, people who could carry out tradition, there were groups representing him, and already married and manjae. However, hatobangon could also abort if he moved Huta (hometown), died, customs offenses and has been dismissed by the kingor the group that appointed him, as well as senile or crazy.

Based on this, the purpose of this study was to describe the hatobangon mindset at the traditional wedding events in the Angkola area through a transitivity analysis. However, the most focused in this case is at the core of the event in an experience of hatobangon words in the form of constituents of the process.

\section{MATERIAL \& METHOD}

This study was using the data that taken from the 83 clauses of the two texts of hatobangon words in a wedding in the Angkola traditional book. The data was basedn on the hatobangon clause containing constituent process and analyzed in transitivity way with the Functional Systemic Linguistic approach. Then, only the constituents of the process used by hatobangon are analyzed.

\section{RESULTS AND DISCUSSION}

Based on the data analysis that has been done, the study found that from 83 clauses produced by hatobangon, the classification of process constituents was obtained as follows.

Table 1. Classification of hata hatobangon descriptions 


\begin{tabular}{cccc}
\hline Constituent Process & Form & Number & $\%$ \\
\hline Material & Happening & 8 & $9.63 \%$ \\
\hline & Doing & 7 & $8.43 \%$ \\
\hline & Passive Clause & 1 & $1.20 \%$ \\
\hline & Range & 0 & $0 \%$ \\
\hline Mental & Perceptive & 4 & $4.81 \%$ \\
\hline & Affective & 3 & $3.61 \%$ \\
\hline Verbal & Cognitive & 1 & $1.20 \%$ \\
\hline Behavior & & 8 & $9.63 \%$ \\
\hline Relational & Mental & 19 & $22.89 \%$ \\
\hline Extra & Verbal & 11 & $13.25 \%$ \\
\hline & & 14 & $16.86 \%$ \\
\hline & $\sum$ & 7 & $8.43 \%$ \\
\hline
\end{tabular}

Based on table 1, it can be explained that a hatobangon in delivering his words at a traditional wedding event in Angkola is more likely to use the process: behavioral: mental as much as $22.89 \%$ and process: relational as much as $16.86 \%$. The reason for using the process: behavioral: mental by hatobangon because the figure has a mental attitude that is wise in conveying something. His expertise in giving life advice has greatly honed his experience in bringing up the process: behavioral: mental when speaking. In addition, the role model for the community made hatobangon tend to use this process in carrying out its traditional role as the hatobangon. To see how the form of the process: behavioral: mental that has been raised by a hatobangon, researchers will present it in table analysis 2 . in the following.

Table 2. Process: Behavioral: Mental

\begin{tabular}{ccc}
\hline Magabe & Hamu & at hadamean \\
\hline 'improved' & 'you' & 'in peace' \\
\hline Process: behavioral: mental & Behaver & Circumstance: cause: condition \\
\hline \multicolumn{3}{c}{ "You are improving in peace" } \\
\hline
\end{tabular}

Based on table 2, it can be explained that magabe 'improves' is process: behavioral: mental. This is because in this process there are mental elements behind the physical process because improving is a verb word class which means being good. Being good means requiring a serious mental attitude process because making a change requires struggle and sincerity. Thus, this process is a mental attitude that cannot be seen but can be manifested in the form of behavior.

Then, related to process use: relational occurs because in giving advice or wise words from a hatobangon in the traditional wedding ceremony in Angkola, majority used parable that symbolized by certain objects. The symbol of the meaning of life through these objects aims to be more easily understood and interpreted by the bride. This makes hatobangon tend to issue a process: relational to support what he wants to convey. This symbolic meaning requires good experience and understanding because in tradition all have been determined and have been agreed upon from ancestors from generation to generation. One form of process can be seen in table 3. below. 
Table 3. Process: Relational

\begin{tabular}{cc}
\hline I ma & burangir sampe-sampe \\
\hline 'That's & Conveyor Sirih* \\
\hline Token | Process: relational: identification & Value \\
\hline \multicolumn{2}{c}{ 'That is Conveyor sirih* } \\
\hline \multicolumn{2}{c}{ ' }
\end{tabular}

(*kinds of leave that symbolized as a present in Angkola Present)

Based on table 3. it can be explained that ima 'that is ' is the token that conflate with process: relational: identifier as a realization for value (burangir sampe-sampe 'conveyor sirih'). Thus, this process is a process: relational: identification.

According to the explanation above, it can be stated that the process constituents that tend to be used by hatobangon in conveying marriage advice in Angkola language tend to use processes: mental: behavioral and relational processes as characteristics of hatobangon thinking full of life wisdom advice and giving examples of life through parables in the relational process for the bride and groom. Thus, they become equipped, hold, and have confidence in living their future lives.

\section{CONCLUSION}

The findings of this paper have proven that the tendency of a person's mindset can be traced from the constituents of the process used to convey something. Similarly, the analysis of hatobangon in this study, from the six process constituents used and from 83 clauses analyzed from the marriage advice text of hatobangon Angkola.

It turns hatobangon uses two very prominent processes from other process constituents, namely processes: mental: behavioral $(22.89 \%)$ and process: relational $(16.86 \%)$. This happened because of the tendency of hatobangon, who was in charge of providing life advice, that hatobangon could not be separated from the two processes.

Furthermore, the use of the two constituents of the process is very supportive of the role of hatobangon in conveying his thoughts at a wedding event at Angkola. The paper related to the analysis of process constituents on marriage advice still needs to be developed, considering there are still other aspects that have not been revealed, both the constituents of the participants and the constituents of the circum. It is hoped that further research can develop this analysis so that later it can add to the theoretical building framework in the constituent parts of the process which are included in the part of the experiential process in particular, and for Functional Systemic Linguistics in general.

\section{ACKNOWLEDGMENTS}

I thank BUDI DN-LPDP RI scholarship for sponsoring me. I am very grateful to the advisor and the co advisors from Universitas Sebelas Maret Surakarta who have supported me to participate in this journals. I also thank to my institution, Universitas Muhammadiyah Tapanuli Selatan for its support for me

\section{REFERENCES}

[1] S. Tinggi Barani and Z. E. Hasibuan, Adat budaya Batak Angkola menelusuri 
perjalanan masa. Medan: Partama Mitra Sari, 2017.

[2] et. al. Tinggi Barani, Sutan, Burangir na hombang. Medan: Parmata Mitra Sari, 2016.

[3] B. Busro and H. Qodim, "Perubahan Budaya dalam Ritual Slametan Kelahiran di Cirebon, Indonesia," J. Stud. Agama dan Masy., vol. 14, no. 2, pp. 127-147, Sep. 2018.

[4] A. Pattiroy and I. Salam, "Tradisi Doi" Menre' dalam Pernikahan Adat Bugis Di Jambi," Al-Ahwal, vol. 1, no. 1, pp. 89-116, 2008.

[5] D. S. Septiningsih, "Persiapan Pernikahan Laki-laki Banyumas (Perspektif Etic dan Emic pada Kesejajaran dengan Praktek Prostitusi)," Psycho Idea, vol. 8, no. 2, pp. 113, 2010.

[6] Mulyana, "Struktur, estetika, dan perubahan konteks dalam wacana pidato upacara perkawinan masyarakat Jawa," Litera, vol. 10, no. 2, pp. 126-134, 2011.

[7] F. A. R. Umar, "Wacana tujaqi pada prosesi adat perkawinan masyarakat suwawa provinsi gorontalo," Bhs. dan Seni, vol. 39, no. 1, pp. 27-37, 2011.

[8] N. Yuliati, "Pemaknaan, Penyesuaian, dan Komunikasi dalam Perkawinan pada Dosen Perempuan," Mimbar, vol. 28, no. 2, pp. 145-156, 2013.

[9] M. Rusli, "Reinterpretasi adat pernikahan suku Bugis Sidrap," KARSA, vol. 20, no. 2, pp. 242-256, 2012.

[10] M. L. Maknun, “Tradisi pernikahan Islam Jawa Pesisir,” Ibda' J. Kebud. Islam, vol. 11, no. 1, pp. 119-130, 2013.

[11] et. al. Hoesni, Suzana Mohd., "Love and marital satisfaction among urban malays: comparing three groups length of marriage," J. Psikol. Malaysia, vol. 30, no. 2, pp. 32 41, 2016.

[12] M. Maulana, "Upacara Daur Hidup dalam Pernikahan Adat Sunda," Refleksi, vol. 13, no. 5, pp. 623-640, 2013.

[13] Lutfiyah, "Relasi budaya dan agama dalam pernikahan," J. Huk. Islam, vol. 12, no. 1, pp. 1-8, 2014.

[14] Yafie, "Adat memberi hibah pelumpat dalam pelangkahan pernikahan di Macanmati, Girimulyo, Panggang, Gunung Kidul,” Al-Ahwal, vol. 7, no. 2, pp. 155-164, 2014.

[15] Sirojuddin and M. B. Asyari, "Tradisi 'Nyare-Dhina' dalam penentuan hari pernikahan perspektif hukum Islam di Desa Larangan Badung," Al-Ihkam, vol. 9, no. 1, pp. 22-40, 2014.

[16] D. Arroisi, Rivial Haq \& Quraisyin, “'Arranged Married' dalam budaya patriakhi (studi kasus komunikasi budaya pada pernikahan di desa Ambuten, Kabupaten Sumenep)," Komunikasi, vol. 9, no. 2, pp. 131-140, 2015.

[17] et. al. Daulay, Ismail Rahmad, "Nilai-nilai edukatif dalam lirik nyayian onang-onang pada acara pernikahan suku Batak Angkola Kabupaten Tapanuli Selatan Provinsi Sumatera Utara," J. Bahasa, Sastra dan Pembelajaran, vol. 1, no. 3, pp. 82-96, 2013.

[18] H. R. Pulungan, "Mencegah terjadinya pernikahan sedarah dengan memahami partuturon dalam masyarakat Batak Angkola-Mandailing," Fitrah, vol. 1, no. 2, pp. 307-324, 2015.

[19] I. G. W. S. Bandana, "Kalimat imperatif dalam wacana perkawinan adat bali," Aksara, vol. 28, no. 2, pp. 227-239, 2016.

[20] et. al. Al Hidaya, Ardian, "Nilai-nilai religious dalam tindak tutur pada prosesi temu manten upacara pernikahan adat Jawa di Kota Madiun," An-Nuha, vol. 3, no. 1, pp. 7391, 2016.

[21] L. Andriani and Z. Khasiah, "Komunikasi simbolik dalam upacara pernikahan manjapuik marapulai di nagari paninjauan Sumatera Barat," J. Komun. ASPIKOM, vol. 2, no. 6, pp. 396-409, 2016. 
[22] A. Mu'in and M. Hefni, "Tradisi Ngabulâ di Madura (Sebuah Upaya Membentuk Keluarga Sakinah bagi Pasangan Muda)," KARSA, vol. 24, no. 1, pp. 109-125, 2016.

[23] Muyassarah, "Nilai budaya walimah perkawinan (walimatul urusy) dalam pemberdayaan ekonomi masyarakat (studi kasus di Kelurahan Gondoria Ngaliyan Semarang)," Inferensi, J. Penelit. Sos. Keagamaan, vol. 10, no. 2, pp. 539-558, 2016.

[24] A. Sulissusiawan, "Peran muhakam dalam adat perkawinan sebagai representasi adab dan etika Melayu Sambas," Litera, vol. 15, no. 2, pp. 351-365, 2016.

[25] S. Azis, "Tradisi pernikahan adat Jawa keraton membentuk keluarga sakinah," Ibda' J. Kebud. Islam, vol. 15, no. 1, pp. 22-41, 2017.

[26] N. I. Hl, "Politeness Strategy in Directive Speech Acts of Tolea Pabitara on Traditional Marriage Ceremony of Tolaki-Mekongga Ethnic," in Globalilluminators, 2017, vol. 3, pp. 35-41.

[27] R. A. Marta, "Tindak tutur ilokusi dalam negosiasi upacara meminang: kajian etnografi komunikasi," Bahastra, vol. 37, no. 1, pp. 58-72, 2017. 